Sains Malaysiana 46(4)(2017): 567-573

http://dx.doi.org/10.17576/jsm-2017-4604-08

\title{
Assessment of Abdominal Obesity using 3D Body Scanning Technology
}

(Penilaian Obesiti Abdomen menggunakan Teknologi Pengimbasan Badan 3D)

\author{
SuHANA JAPAR, THAMIlVAANi MANAHARAN, ASMA AHMAD SHARIFF, ABdUl MAJID MOHAMED \\ \& AMIR FEISAL MERICAN AlJUNID MERICAN*
}

\begin{abstract}
Abdominal obesity is an important contributor for health risk factors such as hypertension, diabetes mellitus and hypercholesterolemia. Therefore, the application of a proper method is important prerequisite in performing abdominal obesity assessment. In this study, we applied 3D body scanning technology to measure waist circumference (WC), hip circumference $(\mathrm{HC})$ and waist to hip ratio (WHR) precisely in an effort to improve the current health assessment for abdominal obesity. A total of 200 Malaysian women with sedentary lifestyle, aged between 18 and 60 years participated in this study. Paired t-test was used to determine the differences between the automated (3D body scanner) and manual measurements of WC, HC and WHR. 3D body scanner measurements show that $27 \%$ of subjects had mild abdominal obesity $(80-90 \mathrm{~cm})$ and $34.5 \%$ of subjects had severe abdominal obesity $(\geq 90 \mathrm{~cm})$ based on WC cutoff points. Based on WHR cutoff points, $57 \%$ of subjects had abdominal obesity $(\geq 0.85)$ while the remaining were without abdominal obesity $(<0.85)$. Lower percentages of abdominal obesity prevalence were reported for both WC and WHR categories using manual measurements. We also found that in normal BMI category, $8.5 \%$ of subjects have mild abdominal obesity based on automated measurements while only $5.5 \%$ of subjects were identified on manual measurements. The result of this study indicated that 3D body scanner provided better assessment method as it enables detection of abdominal obesity in more subjects based on WC and WHR categories. Public agencies are encouraged to consider the application of $3 D$ body scanning in health assessment of abdominal obesity.
\end{abstract}

Keywords: Abdominal obesity; body mass index; waist circumference; waist to hip ratio; $3 D$ body scanner

ABSTRAK

Obesiti abdomen adalah penyumbang penting kepada faktor risiko kesihatan seperti tekanan darah tinggi, kencing manis dan hiperkolesterolemia. Oleh itu, penggunaan kaedah yang betul adalah satu komponen penting dalam menjalankan penilaian obesiti abdomen. Dalam kajian ini, kami menggunakan teknologi pengimbasan badan tiga dimensi (3D) untuk mengukur lilitan pinggang, lilitan ping gul dan nisbah pinggang ke pinggul secara tepat dalam usaha untuk meningkatkan penilaian kesihatan semasa bagi obesiti abdomen. Seramai 200 wanita Malaysia yang berusia antara 18 hing ga 60 tahun mengambil bahagian dalam kajian ini. Ujian-t berpasangan digunakan untuk menentukan perbezaan antara automatik (pengimbas badan 3D) dan ukuran manual WC, HC dan WHR. Ukuran pengimbas badan 3D menunjukkan bahawa $27 \%$ daripada subjek mempunyai obesiti abdomen sederhana $(80-90 \mathrm{~cm})$ dan $34.5 \%$ daripada subjek mempunyai obesiti abdomen teruk ( $\geq 90 \mathrm{~cm}$ ) berdasarkan kategori WC. Berdasarkan kategori WHR, 57\% daripada subjek mempunyai obesiti abdomen ( $\geq 0.85)$ manakala selebihnya adalah tanpa obesiti abdomen $(<0.85)$. Peratusan yang lebih rendah untuk obesiti abdomen dilaporkan bagi kedua-dua kategori WC dan WHR menggunakan ukuran manual. Kami juga mendapati bahawa dalam kategori indeks jisim tubuh (BMI) normal, 8.5\% daripada subjek mempunyai obesiti abdomen yang sederhana berdasarkan pengukuran automatik manakala hanya 5.5\% daripada subjek berdasarkan ukuran manual. Hasil kajian ini menunjukkan bahawa pengimbas badan 3D menyediakan kaedah penilaian yang lebih baik kerana ia membolehkan pengesanan lebih banyak subjek yang mempunyai obesiti abdomen berdasarkan kategori WC dan WHR. Agensi awam digalakkan untuk mempertimbangkan penggunaan pengimbasan badan 3D dalam penilaian kesihatan untuk obesiti abdomen.

Kata kunci: Indeks jisim tubuh; lilitan pinggang; nisbah pinggang ke pinggul; obesiti abdomen; pengimbas badan $3 D$

\section{INTRODUCTION}

Abdominal obesity prevalence has been consistently higher in women compared to men (Chopra et al. 2013). It has been shown that abdominal obesity is an important contributor to major causes of health risk factors such as hypertension, diabetes mellitus and hypercholesterolemia
(Chopra et al. 2013; Norafidah et al. 2013). In public health and clinical settings, body mass index (BMI) has been widely used to define overall obesity. But, BMI does not differentiate on body fat distribution (Wu et al.2014). Thus, it is really important to utilize proper methods in obesity assessment to avoid from neglecting the individuals 
who has the tendency to develop abdominal obesity even though they have normal BMI.

A few researchers have reported that, anthropometric measurements can be used as important indicator for obesity assessment (Fryar et al. 2012; Kuehnapfel et al. 2016). Anhropometric data of body circumferences such as waist circumference (WC), hip circumference (HC) and waist to hip ratio (WHR) are currently been used as simple tools for evaluating the health status, disease risk and to estimate body fat distribution (Fryar et al. 2012; Wu et al. 2014). These circumference measurements provide more detailed information about human body shape and size (Wells et al. 2008). Previous study suggested that WC is a promising tool for assessing the distribution of fat in the human body (Yang et al. 2011). It is an important issue for measuring adiposity and predicting its future since obesity has become a major health problem in contemporary society and can be a risk factor for developing noncommunicable diseases (Dong et al. 2015). In another study, the combination of WC and WHR has been suggested to be a better indicator for obesity-related diseases than BMI alone (Wang et al. 2015).

Recent developments in three dimensional (3D) whole body scanning technologies have enabled instant and accurate collection of body circumferences by non-invasive approaches (Paquette 1996; Simmons \& Istook 2002). The nature of this technology which are low cost, non invasive character and ease of use make it suitable for widespread clinical applications and for large epidemiological survey (Treleaven \& Wells 2007). Moreover, for human clinical research and practice, it is important to precisely measure body composition, shape, surface area and volume that can be obtained through 3D body scanning technology (Soileau et al. 2016).

In the current healthcare settings, WC and $\mathrm{HC}$ are usually obtained through manual measurements using flexible but non-stretchable tapes according to guidelines by the World Health Organization (WHO). However, standardize, precise and accurate measurement of WC and $\mathrm{HC}$ is often challenging, time consuming, error prone and may require assistance, especially in obese individuals. With the advancement of 3D scanning technology, these obstacles can be overcome where $3 \mathrm{D}$ body scanner could provide more accurate and precise circumference measurements (Jaeschke et al. 2015). These measurement data can also be stored on computer system and retrieved whenever required (Treleaven \& Wells 2007). Apart from that, physical contact between the practitioners and the subjects can be minimized (Kuehnapfel et al. 2016). One of the important features of 3D body scanner is to produce $3 \mathrm{D}$ images of human body which cannot be obtained through manual measurement techniques. To the best of our knowledge there is still lack of research regarding obtaining anthropometric measurement in an epidemiologic field in Malaysia. Thus, in our study, we focus on the application of 3D body scanning technology to measure WC, HC and WHR for a better health assessment in early detection of abdominal obesity.

\section{MATERIALS \& METHODS}

\section{DATA COLLECTION}

A total of 200 healthy Malaysian women were recruited based on age (18-60 years) and ethnicity (Malays, Chinese and Indians). Subjects were briefed on the study and asked to sign consent forms to ensure confidentiality. Sociodemographic characteristics of the subjects were obtained through a self-structured questionnaire. Anthropometric data were obtained by trained research staff.

\section{ANTHROPOMETRY}

Manual measurement Body weight was measured with light clothing and without shoes on a calibrated body composition monitor and scale (Omron HBF 514C). Subjects were asked to stand straight on the center of the weight scale platform with their weight evenly distributed on both feet. Weight was recorded to the nearest $0.1 \mathrm{~kg}$. For height measurements, the Seca body meter (Seca, Germany) was used. Subjects were required to stand straight on the floor board of the body meter with their backs to the vertical backboard of the body meter scale. Height was recorded to the nearest $0.1 \mathrm{~cm}$. BMI was calculated as the ratio of weight $(\mathrm{kg})$ to height $\left(\mathrm{m}^{2}\right)$. The subjects were divided into four groups according to BMI categories as reported by World Health Organization (WHO) for Asian (WHO 2004); underweight (less than $18.5 \mathrm{~kg} / \mathrm{m}^{2}$ ), normal $\left(18.5-23.0 \mathrm{~kg} / \mathrm{m}^{2}\right)$, overweight $\left(23.0-27.5 \mathrm{~kg} / \mathrm{m}^{2}\right)$ and obese (more than $27.5 \mathrm{~kg} / \mathrm{m}^{2}$ ).

Measurements of WC and HC were conducted using non elastic measuring tape (Myotape, AccuFitness LLC, USA). For WC measurements, the area of the right iliac crest of the subject was palpated by the measurer by standing behind the subject. A horizontal line is marked at the high point of the iliac crest and the line is crossed to indicate the mid-auxiliary line of the body. For hip measurements, the subjects had to stand erect with feet close together and weight evenly distributed on both feet. The measuring tape was then placed at the maximum extension of the buttocks. The measurer then adjusted the sides of the tape and checked the front and sides to make sure that the plane of the tape was horizontal. The measurement was recorded at the nearest $0.1 \mathrm{~cm}$. All the measurements were taken twice and reported as the mean value of the two measurements.

Automated measurement (3D body scanner) All subjects were requested to wear a special scan-wear which consisted of two-piece garments. These scanning garments were made from light brown fabric with a mixture of lycra and cotton and came in five different sizes: extra-small (XS), small (S), medium (M), large (L) and extra-large (XL). Subjects then took the standardize standing position and held the stabilizing handholds of the scanner to maintain the correct positions during scanning in the NX-16 body scanner (Cary, North Carolina, USA). These procedures were repeated twice to obtain reliable and consistent scanning measurements. The 3D scanner was 
well calibrated to avoid false positive readings. The circumference measurements of WC and HC from each scan were automatically extracted using MS ISO8559 from the Body Measurement System Software (ver.7.4.1, [TC $]^{2}$ ).

WC and WHR WC and WHR were used as a tool to identify abdominal obesity. WHR was calculated as the ratio of WC to $\mathrm{HC}$ (WC:HC). We followed cutoff points from a previous study in determining abdominal obesity (Wu et al. 2014). The WC categories for women are as follows: (i) without abdominal obesity (normal); $<80 \mathrm{~cm}$, (ii) mild abdominal obesity; $80-90 \mathrm{~cm}$, and (iii) severe abdominal obesity; $\geq 90 \mathrm{~cm}$. The WHR categories are as follows: (i) without abdominal obesity (normal); $<0.85$, and (ii) with abdominal obesity; $\geq 0.85$.

\section{STATISTICAL ANALYSES}

The Statistical Package for the Social Sciences (SPSS) version 22.0 (IBM SPSS Statistics, Armonk, NY, USA) was used for analysis. For the purpose of sample description, all variables were presented as mean or frequency, where appropriate. Paired t-tests were used to compare differences in WC, HC and WHR data derived from automated and manual measurements. The level of significance used was $p<0.05$.

\section{RESULTS}

\section{DEMOGRAPHIC CHARACTERISTICS OF SUBJECTS}

A total of 200 women participated in this study were with the mean age of 29.83 years and mean BMI of $25.57 \mathrm{~kg} / \mathrm{m}^{2}$. There were four BMI categories of subjects; underweight, normal, overweight and obese. Approximately 54.5\% were in the category of overweight and obesity while $34.5 \%$ were with normal category and the rest were in the underweight category.

\section{ABDOMINAL OBESITY PREVALENCE: MANUAL VS. AUTOMATED MEASUREMENT}

The differences between circumference measurements taken by $3 \mathrm{D}$ body scanner and manually were determined by paired t-tests analyses and the results are shown in Table 1. Our results showed that there were significant differences $(* p<0.05)$ between manual and automated measurements of WC while HC and WHR showed highly significant differences $(* * p<0.01)$. The 3D body scanner produced higher readings in $\mathrm{WC}$ and $\mathrm{HC}$ circumference measurements compared to the manual measurements (Table 1) indicating the inaccuracy of the manual measurements. As shown in Figure 1(a), there were 27\% of subjects having mild abdominal obesity and $34.5 \%$ of subjects have severe abdominal obesity as determined by WC cutoff points for automated measurements. Based on WHR cutoff points (Figure 1(b)), 57\% of subjects had abdominal obesity and $43 \%$ without abdominal obesity for automated measurements. For manual measurements, lower percentages were reported for both WC and WHR categories.

Table 2 shows the distribution of abdominal obesity prevalence according to BMI categories using manual and automated measurements of WC and WHR. The data were compared based on BMI categories. For underweight and overweight categories, there were almost no differences between manual and automated measurements. Interestingly, our results showed that even in normal BMI, there were subjects having abdominal obesity based on their WC and WHR measurements. We found that more subjects having abdominal obesity using automated measurement according to their WC cutoff point with $8.5 \%$ of them had mild obesity compared to manual measurement with only $5.5 \%$. Figure 2(a) shows $3 \mathrm{D}$ images of subjects with normal BMI based on their WC categories that were chosen based on wC cutoff points: Without abdominal obesity (normal), mild abdominal obesity and severe abdominal obesity. Figure 2(b) shows $3 \mathrm{D}$ images of subjects with normal BMI based on their WHR categories that were chosen based on WHR cutoff points without abdominal obesity and with abdominal obesity. The 3D images show the differences in body shape and size especially at the waist and hip regions for those with normal BMI, which provides an added advantage compared to manual measurements.

\section{DISCUSSION}

In the present study, the prevalence of abdominal obesity was found to be higher using automated measurements compared to manual measurements. Generally, the automated measurements generate significantly higher readings of $\mathrm{WC}, \mathrm{HC}$ and WHR compared to the manual measurements (Table 1). The 3D body scanner offers the opportunity to harness new technology and remove some of

TABLE 1. Paired t-test of WC, HC and WHR data of subjects retrieved from the manual and automated measurements

\begin{tabular}{lccc}
\hline \multirow{2}{*}{ Measurement methods } & \multicolumn{3}{c}{ Circumference measurements } \\
\cline { 2 - 4 } & WC & HC & WHR \\
\hline \multirow{2}{*}{ Manual } & $84.63 \pm 13.82$ & $94.88 \pm 15.08$ & $0.89 \pm 0.04$ \\
3D body scanner & $85.34 \pm 13.36^{*}$ & $103.47 \pm 11.53^{* *}$ & $0.82 \pm 0.02^{* *}$ \\
\hline
\end{tabular}

Data showed the mean $\pm \mathrm{SD},(n=200)$. Paired t-test analysis showed the significant values $* p<0.05, * * p<0.01$. Denotes: waist circumference (WC), hip circumference (HC), and waist-hip ratio (WHR) 

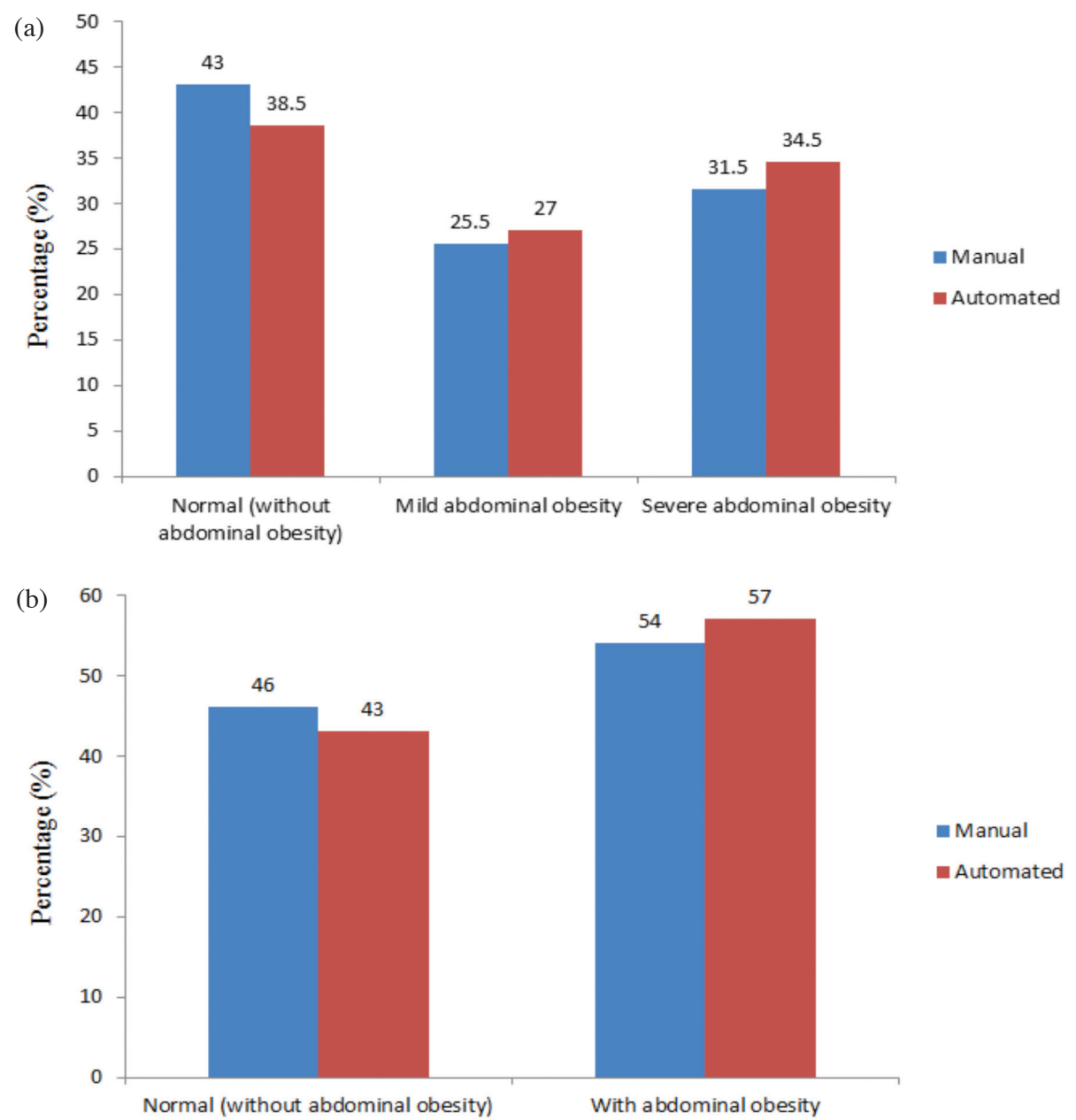

FIGURE 1. Prevalence of abdominal obesity evaluated by automated and manual measurements. The categories were chosen based on (a) WC cutoff points: Without abdominal obesity (WC: $<80 \mathrm{~cm}$ ), mild abdominal obesity (WC: $80-90 \mathrm{~cm}$ ) and severe abdominal obesity $(\mathrm{WC}: \geq 90 \mathrm{~cm}$ ) and (b) WHR cutoff points: without abdominal obesity (WHR: $<0.85$ ) and with abdominal obesity (WHR: $\geq 0.85$ )

the inaccuracies of manual anthropometric measurements (Stefan et al. 2011). The automated measurements showed higher percentages of subjects with abdominal obesity compared to the manual measurements in all BMI categories except for the underweight category (Table 2). Similar results were reported by Jaeschke et al. (2015), where automated measurements of WC and $\mathrm{HC}$ are higher compared to the manual measurement.

Human body is elastic in nature, causing body size to decrease when manual measurements were taken. However, body size remains rigid during the scanning process (Han et al. 2010), a fact that explains why the readings obtained by the 3D body scanner and manually differed (Table 1 ). The risk of tissue constriction and incorrect alignment could be also another reason of lower reading obtained through manual measurement. As for WC measurement, subjects have the tendency to hold their breath and pull in their stomach due to contact during manual measurement either reflexively or consciously. The tissue constriction, tensing of the gluteal muscle and/or not measuring at the correct anatomical landmark could also influence the HC reading during manual measurement. Thus, automated measurement could help to avoid measurement errors that may occur during manual measurement (Jaeschke et al. 2015), which would lead to improper diagnosis of abdominal obesity.

Interestingly, we found subjects even in the normal BMI category having abdominal obesity where the automated measurements shows higher percentages of WC compared to manual measurements (Table 2). In addition, we extracted 3D body images of subjects having normal BMI but with and without abdominal obesity as shown in Figure 2(a) and 2(b), respectively. With the help of 3D images we are able to easily distinguished the body shape and size of those having abdominal obesity. The key benefit of these $3 \mathrm{D}$ scanning images lies on its ability to assess an individual's weight distribution relative to overall physique, hence has the potential to increase the sensitivity of identifying abdominal obesity (Wells et al. 2012).

The $3 \mathrm{D}$ body scanner has its uniqueness in including the fat tissue underneath the skin as part of body dimension during the scanning process, which manual measurements 
unable to provide (Pepper et al. 2010). Even though these subjects have normal BMI, their WC and WHR readings which were more than the cutoff points $(\mathrm{WC} \geq 80 \mathrm{~cm}$; $W H R \geq 0.85$ ) indicated that they have abdominal obesity
(Figures 2(a) and 2(b)). The healthcare personnels who are still practicing the manual measurement techniques are not aware and failed to diagnose these group of people (subjects with normal BMI, with high WC and WHR).

TABLE 2. Distribution of abdominal obesity prevalence according to BMI categories using manual and automated measurements of WC and WHR

\begin{tabular}{lcccccc}
\hline & \multicolumn{2}{c}{$\begin{array}{c}\text { Mild abdominal obesity } \\
\text { using WC }(\%)\end{array}$} & \multicolumn{2}{c}{$\begin{array}{c}\text { Severe abdominal obesity } \\
\text { using WC }(\%)\end{array}$} & \multicolumn{2}{c}{$\begin{array}{c}\text { Abdominal obesity } \\
\text { using WHR }(\%)\end{array}$} \\
\cline { 2 - 7 } BMI category & Manual & Automated & Manual & Automated & Manual & Automated \\
\hline Underweight & 0.5 & 0.5 & 0.5 & 0.5 & 2 & 2 \\
Normal & 5.5 & 8.5 & 0.5 & 0.5 & 9 & 9 \\
Overweight & 15 & 14.5 & 4.5 & 5 & 20 & 21 \\
Obese & 4.5 & 3.5 & 26 & 28.5 & 23 & 25 \\
\hline
\end{tabular}

Data showed the percentages of subjects, $n=200$. Denotes: body mass index (BMI), waist circumference (WC), and waist-hip ratio (WHR)

(a)
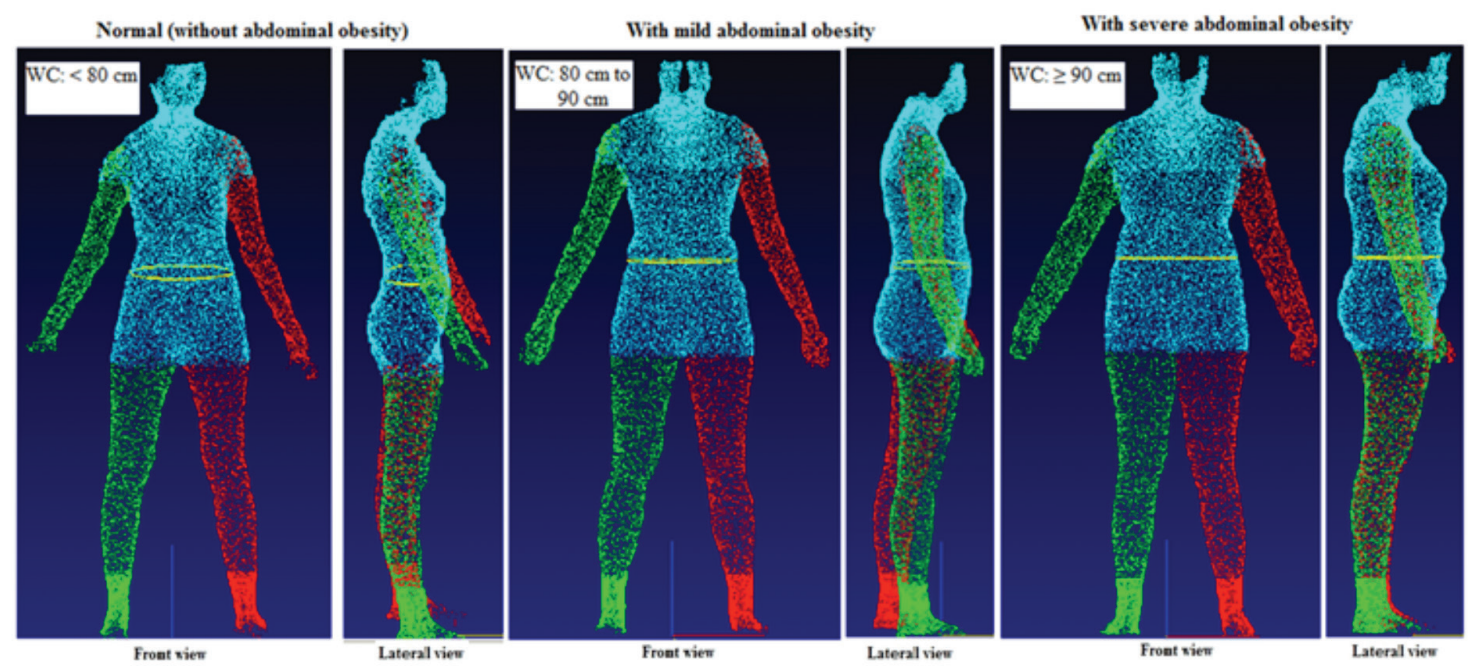

(b)
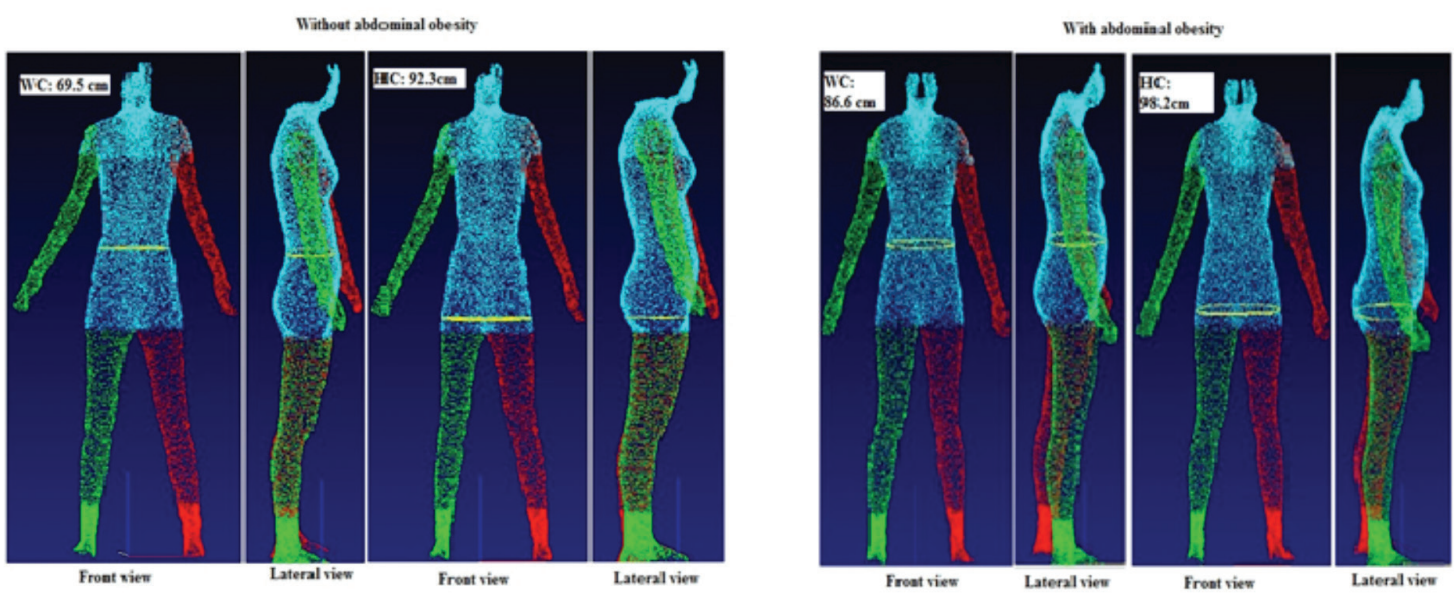

FIGURE 2. (a) The 3D images of subjects in normal BMI according to WC categories that were chosen based on WC cutoff points: Without abdominal obesity (WC: $<80 \mathrm{~cm}$ ), mild abdominal obesity (WC: $80-90 \mathrm{~cm}$ ) and severe abdominal obesity $(\mathrm{WC}: \geq 90 \mathrm{~cm}),(\mathrm{b})$ The 3D images of subjects in normal BMI according to their WHR categories that were chosen based on WHR cutoff point: Without abdominal obesity $($ WHR $<0.85)$ and with abdominal obesity $($ WHR $\geq 0.85)$. The virtual tape measurements of the subjects as depicted in the white boxes; without abdominal obesity (WC: $69.5 \mathrm{~cm}$ and HC: $92.3 \mathrm{~cm}$ ) and with abdominal obesity (WC: $86.6 \mathrm{~cm}$ and $\mathrm{HC}$ : 98.2). The WHR was calculated as ratio of WC to HC; without abdominal obesity (WHR: 0.75) and with abdominal obesity (WHR: 0.88) 
Lacking of awareness and poorer early intervention would lead to the development of non-communicable diseases such as cardiovascular disease in these subjects as well as others (Norafidah et al. 2013). Thus, the 3D body scanner along with $3 \mathrm{D}$ images can be used to obtain precise measurements of body circumferences for early detection of abdominal obesity.

\section{CONCLUSION}

3D scanning technology provide a platform in anthropometry field to measure body circumferences precisely compared to manual measurement. An accurate body circumference measurement play a vital role in the early detection of abdominal obesity. Healthcare providers should consider the application of 3D body scanning in the health assessment of abdominal obesity. This research should be extended, focusing on the relationship between WC and WHR with health status by integrating the application of 3D body scanning technology.

\section{ETHICAL APPROVAL}

The study was approved by the University of Malaya Research Ethic Committee (UMREC) with reference number: UM.TNC2/RC/H\&E/UMREC-63. The purpose and nature of the study was explained to all the subjects, who gave their written consent before participation. This study has been conducted in accordance with the declaration of the World Medical Association Declaration of Helsinki (as amended by the $52^{\text {nd }}$ General Assembly, Edinburgh, Scotland, October 2000).

\section{ACKNOWLEDGEMENTS}

Special thanks to all the subjects for their cooperation in this study. We would also like to thank researcher, Dr. Bong Yii Bonn and all the research assistants (Tahereh Mokhtari, Fatiha Azleen Abdul Rahim and Suhaila Azhar) for their technical support. This study was financially supported by the University of Malaya Research Grant (UMRG); under the UMRG program entitled Phenotypic variations in the Malaysian population: Growth Trajectories of the Malaysian Population using 3D Surface Body Scan Technology (RP004A-13AFR) and The Malaysian Digital Body: A study of size and shape of the Malaysian population (RG001 09AFR), Ministry of Higher Education Fundamental Research Grant Scheme (FRGS): (FP0082014B) and the University of Malaya Postgraduate Research Grant (PG211-2016A). All the authors declare that there is no conflict of interests.

\section{REFERENCES}

Chopra, S.M., Misra, A., Gulati, S. \& Gupta, R. 2013. Overweight, obesity and related non-communicable diseases in Asian Indian girls and women. European Journal of Clinical Nutrition 67(7): 688-696.
Dong, J., Ni, Y.Q., Chu, X., Liu, Y.Q., Liu, G.X., Zhao, J., Yang, Y.B. \& Yan, Y.X. 2015. Association between the abdominal obesity anthropometric indicators and metabolic disorders in a Chinese population. Public Health 131: 3-10.

Fryar, C.D., Gu, Q. \& Ogden, C.L. 2012. Anthropometric reference data for children and adults: United States, 20072010. Vital and Health Statistics 11(252): 1-48.

Han, H., Nam, Y. \& Choi, K. 2010. Comparative analysis of 3D body scan measurements and manual measurements of size Korea adult females. International Journal of Industrial Ergonomics 40(5): 530-540.

IBM SPSS Statistics for windows. Version 22.0. IBM Corp. Armonk, NY: IBM Corp. 2013.

Jaeschke, L., Steinbrecher, A. \& Pischon, T. 2015. Measurement of waist and hip circumference with a body surface scanner: Feasibility, validity, reliability, and correlations with markers of the metabolic syndrome. PloS one 10(3): e0119430.

Kuehnapfel, A., Ahnert, P., Loeffler, M., Broda, A. \& Scholz, M. 2016. Reliability of 3D laser-based anthropometry and comparison with classical anthropometry. Scientific Reports. p. 6.

National Health and Morbidity Survey (NHMS): http://www. moh.gov.my/index.php/file_manager/dl_item/ (Accessed on 1 March 2015).

Norafidah, A.R.,Azmawati, M.N. \& Norfazilah,A. 2013. Factors influencing abdominal obesity by waist circumference among normal BMI population. Malaysian Journal of Public Health Medicine 13(1): 37-47.

Paquette, S. 1996. 3D scanning in apparel design and human engineering. Computer Graphics and Applications 16(5): 11-15.

Pepper, M.R., Freeland-Graves, J.H. \& Yu, W. 2010. Validation of a 3-dimensional laser body scanner for assessment of waist and hip circumference. Journal of the American College of Nutrition 29(3): 179-188.

Simmons, K.P. \& Istook, C.L. 2002. 3-D body scanning measurement procedures: Are they the same as traditional physical anthropometric procedures? In Proceedings of the International Foundation of Fashion Technology Institutes (IFFTI) 4th International Conference, Nov 7-11, Hong Kong Polytechnic University, Hong Kong. pp. 579-590.

Soileau, L., Bautista, D., Johnson, C., Gao, C., Zhang, K., Li, X., Heymsfield, S.B., Thomas, D. \& Zheng, J. 2016. Automated anthropometric phenotyping with novel Kinect-based threedimensional imaging method: Comparison with a reference laser imaging system. European Journal of Clinical Nutrition 70(4): 475-481.

Stefan, D.B., Wohlgemuth, S.D., Gilbert, D.A. 2011. Theory and practical steps to introducing a new 3D public health indicator to replace BMI using existing population based multidimensional reference measurement sets. 5th International 3D Technologies Conference. Lugano, Switzerland. pp. 299-312.

Treleaven, P. \& Wells, J. 2007. 3D body scanning and healthcare applications. Computer 40(7): 28-34.

Wang, S., Liu, Y., Li, F., Jia, H., Liu, L. \& Xue, F. 2015. A novel quantitative body shape score for detecting association between obesity and hypertension in China. BMC Public Health 15(1): 7.

Wells, J.C.K., Ruto, A. \& Treleaven, P. 2008. Whole-body three-dimensional photonic scanning: A new technique for obesity research and clinical practice. International Journal of Obesity 32: 232-238. 
Wells, J.C.K., Treleaven, P. \& Charoensiriwath, S. 2012. Body shape by 3-D photonic scanning in Thai and UK adults: Comparison of national sizing surveys. International Journal of Obesity 36: 148-154

WHO expert consultation. 2004. Appropriate body-mass index for Asian ppopulations and its implications for policy and interventions strategies. The Lancet 36: 157-163.

Wu, S., Wang, R., Jiang, A., Ding, Y., Wu, M., Ma, X., Zhao, Y. \& He, J. 2014. Abdominal obesity and its association with health-related quality of life in adults: A population-based study in five Chinese cities. Health and Quality of Life Outcomes 12(1): 100.

Yang, C.Y., Peng, C.Y., Liu, Y.C., Chen, W.Z. \& Chiou, W.K 2011. Surface anthropometric indices in obesity-related metabolic diseases and cancers. Chang Gung Medical Journal 34(1): 1-22.

\section{Suhana Japar}

Institute of Graduate Studies

University of Malaya

50603 Kuala Lumpur, Federal Territory

Malaysia

Thamilvaani Manaharan, Asma Ahmad Shariff, Abdul Majid Mohamed \& Amir Feisal Merican*

Centre of Research for Computational Sciences and Informatics for Biology,

Bioindustry, Environment, Agriculture and Healthcare (CRYSTAL)

University of Malaya

50603 Kuala Lumpur, Federal Territory

Malaysia
Amir Feisal Merican*

Institute of Biological Sciences, Faculty of Science

University of Malaya

50603 Kuala Lumpur, Federal Territory

Malaysia

Asma Ahmad Shariff \& Abdul Majid Mohamed

Centre for Foundation Studies in Science

University of Malaya

50603 Kuala Lumpur, Federal Territory

Malaysia

Asma Ahmad Shariff \& Abdul Majid Mohamed

Centre for Foundation Studies in Science

University of Malaya

50603 Kuala Lumpur, Federal Territory

Malaysia

*Corresponding author; email: merican@um.edu.my

Received: 15 July 2016

Accepted: 30 September 2016 